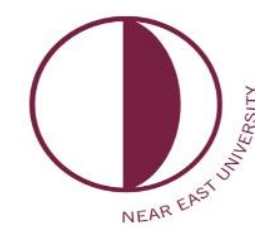

\title{
SPECIAL EDUCATION TEACHERS' ATTITUDES TOWARDS DEVELOPING INDIVIDUALIZED EDUCATION PROGRAMS AND CHALLENGES IN THIS PROCESS
}

\author{
Basak Baglama ${ }^{*}$, Mukaddes Sakalli Demirok ${ }^{2}$, Gonul Akcamete ${ }^{3}$ \\ ${ }^{1}$ Near East University, Atatürk Faculty of Education, Department of Special Education, Nicosia-North Cyprus, \\ Mersin 10-Turkey, basak.baglama@neu.edu.tr \\ ${ }^{2}$ Near East University, Atatürk Faculty of Education, Department of Special Education, Nicosia-North Cyprus, \\ Mersin 10-Turkey, mukaddes.sakalli@ neu.edu.tr \\ ${ }^{3}$ Near East University, Atatürk Faculty of Education, Department of Special Education, Nicosia-North Cyprus, \\ Mersin 10-Turkey, gonul.akcamete@neu.edu.tr \\ Correspondence: basak.baglama@neu.edu.tr ; Tel.: +0392 2236464
}

\begin{abstract}
Individualized education programs (IEP) are special education programs which is prepared for achieving targetted goals for individuals with special needs based on their developmental characteristics, educational performances and needs and includes support educational services for them. It is really important to prepare IEP's based on the current performance level and needs of the individuals with special needs. Accordingly, it is considered that attitudes of special education teachers towards IEP development process and challenges that they experience in this process are important in terms of the effectiveness of IEP's within the scope of this research. Therefore, aim of the present study is to determine the attitudes of teachers working at special education centers in Turkish Republic of Northern Cyprus (TRNC) and challenges that teachers experience during this process. A total number of 65 teachers working at special education centers in TRNC participated in this study. "Attitudes towards the IEP Development Process Scale" and "Challenges faced during IEP Development Process Scale" were used to collect the data of the study. Results have been discussed with the relevant findings from literature and conclusions and recommendations have been provided for further research and special education legislation and practices implemented in TRNC.
\end{abstract}

Keywords: individualized education programs (IEP), IEP development process, attitudes, challenges, special education teachers

\section{Introduction}

It is generally known that special education involves individualized instruction in order to meet the needs of individuals with special needs and requires appropriate educational environments (Cook, Klein, \& Chen, 2015). Educational programs and instructional content need to be adapted and regulated for students with special needs. Individuals with special needs benefit from special education and related support services through IEP's (Akcamete, 2010; Kauffman, Hallahan, Pullen \& Badar, 2018). IEP's are the written documents predicting the benefit of individuals with special needs at the highest level from appropriate educational environments including school, special education, occupational education center etc.) and 
support services (mainstreaming room, in-class help, language and speech therapy, physical rehabilitation, guidance and psychological counseling etc.) in discipline domains (self-care, academic skills, social skills, communication etc.) in line with the development of the individual with special needs and the program applied (Pretti-Frontczak \& Bricker, 2000; Avcioglu, 2015; Baysen \& Dakwo, (2018).

Individualized education programs (IEP) are special education programs developed for every children with special needs by regional educational institutions or special education departments and constituted for meeting the needs of teachers, parents and protective families as well (Meyen \& Bui, 20078). IEP's include plans which show the actions that the individuals with special needs require to fulfill based on the requirements of themselves and how the substages of these actions should be applied (Ozyurek, 2006). Individualized education plan is developed based on considering the individual competencies and characteristics of individuals with special needs in all developmental domains. Two important items that should be included in the IEP are long-term and short-term goals. IEP is prepared for an academic year. Long-term goals are a list of behaviors that will be gained to the student during a school year. Short-term goals are intermediate steps between the student's level of performance and long-term goals (Kargin, 2007).

The attitudes of teachers towards inclusion were closely related to providing appropriate services to students with special needs in education settings (Lee-Tarver, 2006; Boyle, Topping \& Jindal-Snape, 2013). Considering the crucial role of special education teachers in the development and implementation of IEP's and attitudes and experiences of special education teachers are important in predicting their professional practices in special education, it is important to examine their attitudes towards IEP's and their thoughts on the challenges in IEP development process. Therefore, this study aims to identify the attitudes of special education teachers towards IEP development and challenges which might be experienced during this process of IEP development. In line with this aim, answers to the following questions were sought in the study.

1. How are special education teachers' attitudes towards IEP development process?

2. How are special education teachers' thoughts on the challenges experienced in IEP development process?

3. Do special education teachers' attitudes towards IEP development process and thoughts on the challenges experienced in IEP development process show difference according to their:

- Age

- Gender

- Institution

- Status on participating in in-service training

- Duration of participating in in-service training

- Participating in IEP development process? 


\section{Method}

\subsection{Research Model}

General survey method was used in the present study in order to identify the attitudes of special education teachers towards IEP development and challenges which might be experienced during this process of IEP development. General survey method are research methods which tries to determine the existing situation and make a judgment about the population (Karasar, 2009).

\subsection{Study Group}

Study group consisted of 65 special education teachers working at special education schools and rehabilitation centers in Turkish Republic of Northern Cyprus (TRNC). Table 1 shows demographic characteristics of the study group.

Table 1. Demographic characteristics of the study group

\begin{tabular}{cccc}
\hline $\begin{array}{c}\text { Demographic } \\
\text { Characteristics }\end{array}$ & f & \% \\
\hline \multirow{2}{*}{ Age } & $20-27$ & 35 & 53.8 \\
& $28-35$ & 24 & 36.9 \\
& 36 and above & 6 & 9.2 \\
& Total & 65 & 100 \\
Gender & Male & 27 & 58.5 \\
& Female & 38 & 41.5 \\
& Total & 65 & 100 \\
& & & 81.5 \\
& School & 53 & 18.5 \\
& Rehabitution & 12 & 100
\end{tabular}

Status on participating

in in-service training

$\begin{array}{ccc}\text { Yes } & 49 & 75.4 \\ \text { No } & 16 & 24.6 \\ \text { Total } & 65 & 100\end{array}$




\begin{tabular}{cccc}
\hline $\begin{array}{c}\text { Duration of } \\
\text { participating in in- }\end{array}$ & $1-5$ days & 22 & 33.8 \\
service training & 6 days and above & 43 & 66.2 \\
& Total & 65 & 100 \\
Participating in IEP & Yes & 58 & \\
development process & No & 7 & 89.2 \\
& Total & 65 & 10.8 \\
& & & 100 \\
\hline
\end{tabular}

According to Table 1, it is seen that 35 of special education teachers $(53.8 \%)$ were between the ages of 20 and $27 ; 24$ of them (36.9\%) were between 28 and 35 and 6 of them $(9.2 \%)$ were 36 and above. In addition, 27 of special education teachers $(41.5 \%)$ were male and 38 of them $(58.5 \%)$ were female. As it can be seen from the table, majority of the participants work at special education centers $(\mathrm{f}=53,81.5 \%)$. Besides, 49 special education teachers $(75.4 \%)$ participated in an in-service training on IEP development before and 16 of them (24.6\%) did not participate in such an in-service training. Special education teachers reported that they participated in an in-service training for $1-5$ days $(\mathrm{f}=22,33.8 \%)$ and for 6 days and above $(\mathrm{f}=43$, $66.2 \%)$. Approximately $90 \%$ of special education teachers indicated that they participated in IEP development process before.

\subsection{Data Collection Tools}

Demographic information form, "Attitudes towards IEP Development Process Scale" and "Challenges Experienced in IEP Development Process Scale" were used to collected the data. Demographic information form included questions on special education teachers' age, gender, institution that they work, status on participating in in-service training, duration of participating in in-service training and participating in IEP development process. The scales used in the study were developed by Bafra and Kargin (2009). Content and construct validity and reliability studies of the scales were done by Bafra and Kargin (2009). The attitudes scale includes 15 items while the challenge scale includes 20 items. Responses to items in both scales were recorded as "Fully Agree", "Agree", "Indecisive", "Disagree," and "Fully Disagree" on Likert type 5 point scale. Special education teachers were asked to have permission to administer the scales and they were given the scales during their appropriate times.

\subsection{Data Analysis}

All collected data for this current research were analyzed by using 23th version of the Statistical Package for the Social Sciences (SPSS). In order to test the hypothesis of the current 
study data were analyzed by using, t-test analysis, One-way ANOVA and Pearson correlation. Findings were interpreted as statistically significant at $\mathrm{p} \leq 0.05$ level.

\section{Results}

In this section, statistical analysis results on special education teachers' attitudes towards IEP development and challenges experienced in this process are provided.

3.1. T-test results on attitudes towards the IEP development process related with gender, Institution, participating in in-service training, duration of participating in inservice training and participating in IEP development process

Table 2. T-test results of perceptions on teaching arts based on gender and receiving a lecture on teaching arts or not

\begin{tabular}{|c|c|c|c|c|c|c|}
\hline & & $\mathbf{n}$ & Mean & SD & $\mathbf{t}$ & $\mathbf{p}$ \\
\hline \multirow[t]{2}{*}{ Gender } & Male & 27 & 46.59 & 4.58 & -1.25 & .926 \\
\hline & Female & 38 & 45.05 & 5.08 & & \\
\hline \multirow[t]{3}{*}{ Institution } & School & 53 & 45.67 & 5.28 & -.045 & .186 \\
\hline & Rehabilitation & 12 & 45.75 & 2.83 & & \\
\hline & Center & & & & & \\
\hline \multirow{2}{*}{$\begin{array}{l}\text { Status on participating } \\
\text { in in-service training }\end{array}$} & Yes & 49 & 45.45 & 5.35 & -.697 & .077 \\
\hline & No & 16 & 46.43 & 3.18 & & \\
\hline \multirow{2}{*}{$\begin{array}{l}\text { Duration of } \\
\text { participating in in- } \\
\text { service training }\end{array}$} & 1-5 days & 22 & 44.36 & 6.22 & -1.580 & $.028^{*}$ \\
\hline & $\begin{array}{l}6 \text { days and } \\
\text { above }\end{array}$ & 43 & 46.37 & 3.99 & & \\
\hline \multirow{2}{*}{$\begin{array}{l}\text { Participating in IEP } \\
\text { development process }\end{array}$} & Yes & 58 & 45.71 & 5.15 & .068 & .131 \\
\hline & No & 7 & 45.57 & 2.14 & & \\
\hline
\end{tabular}

T-test analysis was applied to determine whether attitudes of special education teachers show significant difference based on gender, institution that they work, status on participating in in-service training, duration of participating in in-service training and participating in IEP development process. Table 2 shows detailed information on t-test results of attitudes of special education teachers and various variables. As it can be seen from the table, attitudes of special education teachers towards IEP development process show significant difference only based on gender $(\mathrm{t}(65)=-1.580, \mathrm{p}<.05)$. It is seen that special education teachers who participated in longer in-service training sessions on IEP development scored higher special education teachers who participated in trainings lasting for between 1 and 5 days. However, results also 
showed that attitudes of special education teachers did not show significant difference based on other variables including gender, institution that they work, status on participating in inservice training and participating in IEP development process.

\subsection{One-way ANOVA results on IEP development process related with age}

Table 3. One-way ANOVA results of perceptions on teaching arts based on age and class level

\begin{tabular}{cccccccc}
\hline Variable & & n & & $\begin{array}{c}\text { Sum of } \\
\text { Squares }\end{array}$ & $\begin{array}{c}\text { Mean } \\
\text { Square }\end{array}$ & F & p \\
& & & & & \\
\hline Age & $20-27$ & 35 & Between & 7.058 & 14 & 1.200 & .305 \\
& $28-35$ & 24 & groups & & & & \\
& 36 & 6 & Within & 21.003 & 50 & & \\
& and & & groups & & & & \\
& above & & & & & & \\
& & & & & & \\
& & &
\end{tabular}

Table 3 shows one-way ANOVA analysis results which was done to reveal whether attitudes of special education teachers show significant difference on age. Results showed that attitudes of special education teachers did not show significant difference based on their age. Therefore, it can be inferred that attitudes of special education teachers do not change according to their ages.

3.3. T-test results on challenges experienced during preparing IEP's related with gender, mstitution, participating in in-service training, duration of participating in inservice training and participating in IEP development process

Table 4. T-test results of perceptions on teaching arts based on gender and receiving a lecture on teaching arts or not

\begin{tabular}{ccccccc}
\hline & & n & Mean & SD & t & p \\
\hline \multirow{3}{*}{ Gender } & Male & 27 & 47.93 & 10.44 & .290 & .260 \\
& Female & 38 & 48.81 & 13.27 & & \\
& & & & & & \\
\hline \multirow{2}{*}{ Institution } & School & 53 & 49.34 & 11.63 & 1.257 & .180 \\
& Rehabilitation & 12 & 44.50 & 13.82 & & \\
& Center & & & & & \\
\hline
\end{tabular}




\begin{tabular}{ccccccc}
\hline Status on participating in & Yes & 49 & 47.00 & 10.82 & -1.712 & .094 \\
in-service training & No & 16 & 52.87 & 14.89 & & \\
\hline \multirow{2}{*}{$\begin{array}{c}\text { Duration of participating in } \\
\text { in-service training }\end{array}$} & $1-5$ days & 22 & 46.90 & 12.18 & -.730 & .618 \\
& 6 days and & 43 & 49.23 & 12.12 & & \\
\hline above & & & & & \\
Participating in IEP & Yes & 58 & 47.41 & 12.17 & -2.028 & .082 \\
development process & No & 7 & 57.00 & 7.48 & & \\
\hline
\end{tabular}

In order to determine whether special education teachers' experiences on challenges during IEP development process show significant difference based on gender, institution that they work, status on participating in in-service training, duration of participating in in-service training and participating in IEP development process, T-test analysis was applied. The results are shown in Table 4. As it can be seen from the table, no significant difference was observed between special education teachers' experiences on challenges during IEP development process and their gender, institution that they work, status on participating in in-service training, duration of participating in in-service training and participating in IEP development process.

\subsection{One-way ANOVA results on challenges experienced during preparing IEP's related with age}

Table 5. One-way ANOVA results of perceptions on teaching arts based on age and class level

\begin{tabular}{cccccccc}
\hline Variable & & n & & $\begin{array}{c}\text { Sum of } \\
\text { Squares }\end{array}$ & $\begin{array}{c}\text { Mean } \\
\text { Square }\end{array}$ & F & p \\
& & & & & \\
\hline Age & $20-27$ & 35 & Between & 12.92 & .462 & 1.098 & .391 \\
& $28-35$ & 24 & groups & & & & \\
36 & 6 & Within & 15.13 & .420 & & \\
& and & & groups & & & & \\
& & & & & & \\
\hline
\end{tabular}

Table 5 shows one-way ANOVA analysis results which was done to reveal whether special education teachers' experiences on challenges during IEP development process show significant difference on age. According to the table, special education teachers' challenges during IEP development process did not show significant difference based on their age. 


\section{Discussion}

This study tried to identify the attitudes of special education teachers towards IEP development and challenges which might be experienced during this process of IEP development and relation between the attitudes and experienced challenges and demographic variables including age, gender, institution that they work, status on participating in in-service training, duration of participating in in-service training and participating in IEP development process were also examined.

Results showed no significant difference between special education teachers' attitudes towards IEP development process and challenges experienced in this process and demographic variables. In contrast, Bafra and Kargin (2009) showed that special education teachers' attitudes showed significant difference regarding their gender, institution that they work, status on participating in in-service training, duration of participating in in-service training and participating in IEP development process instead of age. In addition, they also found that age, institution, participation in in-service training on IEP development and involvement in the IEP development process were significantly related with challenges experienced by special education teachers during the process of IEP development. Martinez (2004) also indicated that teaching experience and gender were demographic variables found to be significantly related with attitudes of special education teachers towards IEP's.

According to the results, only significant difference was revealed between special education teachers' attitudes towards IEP development process and duration of participating in in-service training. In other words, special education teachers who participated in longer in-service training sessions on IEP development scored higher special education teachers who participated in trainings lasting for between 1 and 5 days. Can (2015) examined the problems of special education teachers related with IEP's and found that not being able establish an IEP team and lack of healthy and functional application of IEP's are the most experienced problems related with IEP. In parallel with the results of the present study, Can (2015) also found that special education teachers made an emphasis on the need for in-service trainings related with IEP's. Furthermore, Bafra and Kargin (2009) revealed that there is a significant difference between attitudes of special education teachers towards IEP development and duration of participation into an in-service training on IEP development.

\section{Conclusion and Recommendations}

In conclusion, this study provided important results on attitudes of special education teachers working in TRNC towards IEP development process and challenges experiences in this process. The arrangements in the content of undergraduate programs and in-service training programs can be made in the light of the results obtained from the present study. In addition, this study will shed light on future research and practices regarding IEP's prepared and applied in TRNC. Following recommendations for future research and practices are presented based on the results of the study:

1. Seminars, conferences and in-service trainings on preparing effective and functional IEP's for special education teachers should be organized.

2. The content of IEP-related courses included in the special education undergraduate programs can be arranged for improving more practical knowledge skilss and the number of courses can be increased. 
3. Other preservice teachers in the Faculties of Education can be informed more about IEP.

4. Due to their participation in the IEP process, in-service trainings and seminars can be organized for all other professionals working in the field of Special Education.

5. This study can be conducted with more professionals working in the field of special education in TRNC to shed light on IEP practices and policies.

6. Other personal variables such as self-efficacy and professional competence of special education teachers related with IEP's might be examined.

7. Based on a pilot school, a research project in which IEP development and implementation skills of teachers can be proposed by following the IEP development and implementation process step by step with teachers. 


\section{References}

Akcamete, G. (2010). Genel egitim okullarinda ozel gereksinimi olan ogrenciler ve ozel egitim. Ankara: Kok Publishing.

Avcioglu, H. (2015). A'dan z'ye bep: Bireysellestirilmis eğitim programlarının geliştirilmesi. Ankara: Vize Publishing.

Bafra, L., \& Kargin, T. (2009). Investigating the attitudes of elementary school teachers, school psychologists and guidance research center personnel on the process of preparing the individualized educational program and challenges faced during the related process. Educational Sciences: Theory and Practice, 9(4), 1959-1972.

Baysen, E., \& Dakwo, P. E. C. (2018). Content analysis of guidance and psychology -sports and related articles. Near East University Online Journal of Education, 1(1), 20-35.

Boyle, C., Topping, K., \& Jindal-Snape, D. (2013). Teachers' attitudes towards inclusion in high schools. Teachers and Teaching, 19(5), 527-542.

Can, B. (2015). Bireysellestirilmis egitim programi ile ilgili ozel egitim ogretmenlerinin yasadiklari sorunlar ve bu sorunlara yonelik cozum onerileri (KKTC ornegi) (Unpublished master thesis). Institute of Educational Sciences, Near East University, TRNC.

Cook, R. E., Klein, M. D., \& Chen, D. (2015). Adapting early childhood curricula for children with special needs. UK: Pearson.

Karasar, N. (2009). Bilimsel arastirma yontemi: Kavramlar-ilkeler-teknikler. Ankara: Nobel Yayin Dağitim.

Kargın, T. (2007). Egitsel degerlendirme ve bireysellestirilmis egitim programi hazırlama sureci. Ankara Universitesi Egitim Bilimleri Fakultesi Ozel Egitim Dergisi, 8(1), 1-15.

Kauffman, J. M., Hallahan, D. P., Pullen, P. C., \& Badar, J. (2018). Special education: What it is and why we need it. London: Routledge.

Lee-Tarver, A. (2006). Are individualized education plans a good thing? A survey of teachers' perceptions of the utility of 1eps in regular education settings. Journal of Instructional Psychology, 33(4), 263-272.

Martinez, R. S. (2004). General education teachers' attitudes toward inclusion: Implications for school psychologists. In Communique, 33(2) 16-17.

Meyen, E. L., \& Bui, Y. N. (2007). Exceptional children in today's schools: What teachers need to know. Denver, CO: Love Publishing.

Ozyurek, M. (2006). Engellilere yonelik tutumlarin degistirilmesi. Ankara: Kok Publishing.

Pretti-Frontczak, K., \& Bricker, D. (2000). Enhancing the quality of individualized education plan (IEP) goals and objectives. Journal of Early Intervention, 23(2), 92-105.

\section{Biodata of the Corresponding Author}

Assist. Prof. Dr. Basak Baglama is lecturer in the department of Special Education at Near East University, North Cyprus. She teaches psychology, autism, individual differences in special education and inclusion courses. Her research interests include autism, inclusive education, teaching mathematics to individuals with special needs and use of technology in special education. 